\title{
BRITAIN AND THE EUROPEAN COMMON MARKET
}

$\mathrm{B}^{\mathrm{n}}$ ROADSHEET No. 465, The Negotiations of Political Union*, part of a major study of Britain and the European Common Market which the Political and Economic Planning Trust began in 1958 with the help of a grant from the Ford Foundation, is the latest in a series of publications issuing from that study. It follows a broadsheet entitled Cartel Policy and the Common Market (No. 464) $t$, issued in August, and an Anglo-French symposium entitled "Aspects of European Integration", produced jointly by P.E.P. and the Institut de Science Economique Appliquée, which was published in September. Broadsheet No. 461, Trade Unions and the Common Market, was issued in May, and Broadsheet No. 454, Economic Planning in France, was issued in August 1961. Occasional Paper No. 12 was re-issued in March 1961 as broadsheet No. 451, Four Approaches to the European Problem, but some eleven occasional papers arising out of the study had then already been published, including one on Agricultural Policy in the European Economic Community and a preliminary appraisal of the European Free Trade Association.

The present broadsheet, by M. Palmer, describes and analyses the various drafts that have provided $a$ basis for discussion among the member States of the European Economic Community on closer political union. It first describes briefly the Community's method of operation to show how this process differs from the procedures envisaged by the French Government for the political field and then describes the French proposals and the reactions to them of the other countries. While the French Government and the Governments of the five other parties in the European Economic Community are agreed on the need for a political relance which will add foreign policy, defence matters and cultural and scientific co-operation to those fields in which the Six already act together, no clear agreement has yet been reached on the precise arrangements which should be made,

* Planning, 28, No. 465; October 1962: The Negotiations on Political Union. Prepared by Michael Palmer. Pp. 295-326. (London Political and Economic Planning, 1962.) 3s. 6d.

+ Planning, 28, No. 464; 27 August, 1962: Cartel Policy and the Common Market. Pp. 199-298. (1,ondon: Political and Economic Planning, 1962.) $7 s .6 d$. nor would agreement on the form and competence of the proposed political union of itself guarantee that common policies can be reached on individual issues in international affairs. The success of the Six in achieving common policies over matters covered by the Treaties of Paris and of Rome is attributed in large measure to their basic community of economic interest.

Broadsheet No. 464, written by M. Forsyth, after considering first the significance of the first regulation on restrictive trade practices in the Common Market which came into force on March 13, 1962, considers in succession national legislation in the European Eeonomic Community and the United Kingdom, the example of the European Iron and Steel Community, and the Rome Treaty and the First Regulation. While there are considerable differences between the six countries of the Common Market and the United Kingdom in their policies towards restrictive prac. tices, each policy has to be seen in terms not only of its written form but also of the method and spirit in which it is applied. Italy and Luxembourg still have no specific legislation on the subject, and while in the United Kingdom, the Netherlands and Belgium the criterion is the 'public interest', in Germany and France the criterion is that of 'restricting competition'. Germany and the United Kingdom have perhaps the most developed restrictive legislation in Europe and both are now encountering the same problems, essentially those relating to resale price maintenance and the process of concentration.

The Common Market's present provisions for restrictive trade practices are based on the prohibition a priori of restrictive agreements; dominant concerns are also forbidden a priori from misusing their power; there are no provisions against mergers, but the Commission has fairly wide powers to investigate sectors of the market if necessary. Appeal is possible to the European Court of Justice. The effectiveness of the rules will depend on how far the various policies and rules of the Community are developed in harmony with them, including how far this policy is balanced by sound common monetary and business cycle policy, in astive regional policy and social measures.

\section{DOMESTIC FOOD CONSUMPTION AND EXPENDITURE IN BRITAIN}

CINCE 1940 yearly surveys have been made of $\checkmark$ food consumption and expenditure on food in private households in the United Kingdom. The reports of these, printed annually since 1950, contain detailed analyses of the findings. Since the investigations are made in various regions and cover representative rural and urban households of all sizes, belonging to different social and economic classes, they bring to light interesting facts about the country's eating habits not shown by national average food supply statistics.

The 1960 survey is the fifth since 1956 , a point at which the conditions created by war and rationing finally ceased to influence the freedom of supply and consumer choice. Changes in eating habits in a free market have occurred during this period, some caused by fluctuating prices rather than by new trends in taste. The see-sawing counter-balances of butter and margarine sales, for example, are related to the price of butter. There are, however, some significant trends in eating habits not due to this cause, one being the increasing popularity of 'convenience foods', bought partly or wholly prepared, and another the remarkable increase of sales of poultry, especially broiler chickens. The average expenditure on 'convenience foods' in 1960 was $5 s$. 6d. per person per week, or 18.7 per cent of the total expenditure on food, as compared with $4 s .8 d$. and $17 \cdot 1$ per cent in 1956. Expenditure on poultry rose from $3 \frac{1}{2} d$. in 1959 to $4 \frac{1}{2} d$. in 1960 per person per week.

Some slower changes have taken place over a longer period of years. The consumption of dairy products has steadily risen, and in 1960 was 42 per cent greater than the 1934-38 level. On the other 
hand, that of potatoes and cereal products, including bread and flour, is decreasing yearly. In 1960 the decrease for potatoes was temporarily halted as they were cheap and plentiful, but over the five-year period decline in purchases can be seen. Purchases of cereal foods are now 14 per cent less than the pre-War level; only $45.5 \mathrm{oz}$. of bread per person per week was purchased in 1960 compared with 47.3 in 1959 and $51.1 \mathrm{oz}$. in 1956. A change of taste is shown in the rapidly growing demand for wrapped bread. Less flour is being bought and more cakes and biscuits.

With respect to 'convenience foods', most of the money is spent on cakes and biscuits, cannod or cooked meat and fish, but 21 per cent is spent on fruit and vegetables and the greatest expansion of demand has been for frozen legumes, mainly peas. In 1956, $0 \cdot 2 \mathrm{oz}$. of frozen legumes per person per week were purchased, rising to $0.63 \mathrm{oz}$. in 1960 . The popularity of frozen foods is indicated by the fact that they are grouped separately in the 1960 report and not included in other groups. Although an average of $5 s .6 d$. per head per week was spent on 'convenience foods', this was by no means uniform. The section on diet and social classes shows that $6 s .3 d$. a week was spent on them by the highest earning income group, but only $4 s$. 10d. by the lowest, while old-age pensioners spent $3 s .11 d$. The section on family composition shows that young childless couples spent $8 s$. $1 d$. per head per week on 'convenience foods' compared with $3 s$. 11 d. spent by families with four or more children. Geographical comparisons indicate that the highest proportion of the total expenditure on foods devoted to 'convenience foods' was in the north of England and Scotland and the lowest in London and the rural areas.

When the housewife goes out to work she has less time but more money to spend on food, and, as a result, she devotes more money to prepared foods. This trend is likely to increase as mass production and competition reduce the price of these foods and make available a greater variety. Enthusiastic lovers of home-cooking evoke little response from harassed housewives who do not want to be 'slogging away over a hot stove' in a machine-minded age, and can afford to buy foods which reduce the slogging.

Although the average value for food consumed (including 'free supplies' from gardens, etc.) was $30 s$. 6d. per person per week in 1960, the highest income group was obtaining food worth $40 s$. $3 d$. and the lowest 27s. 4d. An increase in the basic pensionrate in 1958 was reflected in a welcome increase of expenditure on food by old-age pensioners from $24 s$. $9 d$. in 1956 to $27 s$. $10 d$. in 1960 (the total value being 28s. 6d. including 'free foods'); part of this is, however, accounted for by the rise in food prices since 1956. The expenditure of families of different sizes shows a wide range. Families of two adults under 55 spent $40 s$. $3 d$. per head per week (41s. $2 d$. with 'free foods'), while families with four or more children spent only $19 s .9 d$. (20s. $3 d$. with 'free foods').

The survey showed that the population as a whole had a diet adequate in all respects. The higher expenditure of wealthier families means more expensive foods and a greater variety, but little nutritional advantage except for more vitamin $\mathrm{C}$ resulting from a higher consumption of fruit and vegetables. The blot in this happy picture remains the consumption of families with several children. Households with three children obtained only 92 per cent and 94 per cent of estimated requirements for protein and calcium respectively. Those with four or more children obtained 99 per cent of the energy value neoded, but only 85 per cent of the total protein and 85 per cent of the calcium. Growing children should not go short of protein and calcium. The over-all picture of well-being and rising standards of living, based on encouraging average figures, may conceal the position of some less-fortunate minorities.

Joyce Doughty

\section{FOOD ADDITIVES AND MEAT HYGIENE}

$\mathrm{T}$ WO booklets containing reports of Joint Food and Agriculture Organization/World Health Organization Expert Committees have recently been published. Problems in connexion with the satisfactory control of food additives are discussed in No. 31 of the Food and Agriculturo Organization Nutrition Meetings Report Series, which is entitled Evaluation of the Toxicity of a Number of Antimicrobials and Antioxidants*. Some 86 pages of the booklot contain a series of monographs relating to a selected number of preservatives and antioxidants. The substances chosen for evaluation by the Joint Committee were those which are widely used in many countries and because they play an important part in reducing food wastage by improving storage efficiency and distribution. Specifications for identity and purity of additives were discussed in previous reports of the Committee. The monographs of this, the sixth report of the Joint Committee on Food Additives, therefore, concentrate largely on the

* Food and Agriculture Organization of the United Nations. FAO Nutrition Meetings Report Series. No. 31. Evaluation of the Toxicity of a Number of Antimicrobials and Antioxidants. Sixth Report of th Joint FAO/WHO Expert Committee on Food Additives. Pp. 104 London: H.M. Stationery Office, 1962.) 6s. 8d.; 1.25 dollars. properties that are of the greatest interest to the toxicologist. The biological data are presented under the following headings: acute toxicity, short-term studies, long-term studies and biochemical aspects.

Each monograph records the comments of the Committee on such data, but the report mentions that in most cases they would have liked more evidence from which to draw. For the evaluation of the individual preservatives and antioxidants, the Committee have (wherever possible) estimated: $(a)$ the dosage-level causing no significant toxicological effect (mainly from long-term studies in rats); (b) the acceptable daily intake zones for man (unconditional and conditional). The latter figures are also usefully given in tabular form on page 12. The Committee recommends that the Food and Agriculture Organization and the World Health Organization should use all means available to promote further research and that further committees should be convenod to evaluate the toxic hazards involved in the use of other groups of additives, such as emulsifiers, stabilizers, other preservatives, such as antibiotics, and food colours. It is interesting to note, however, that this report states that ". . . the needs for food additives and their possible uses and applications vary so widely 